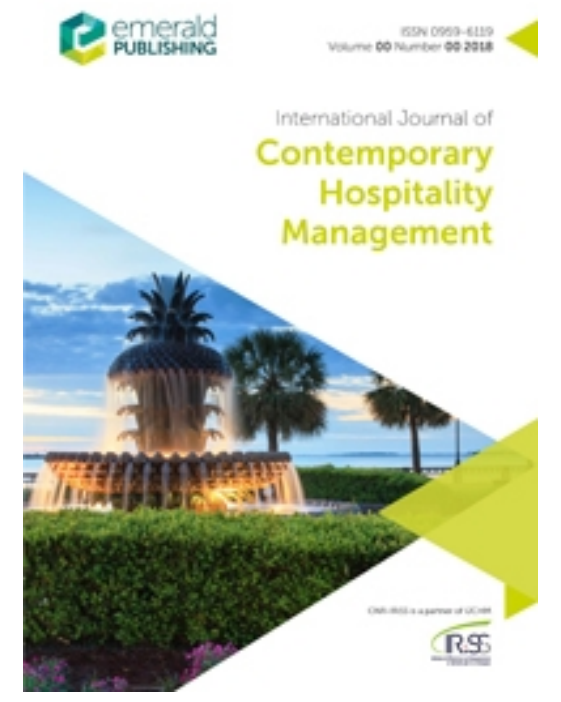

\title{
Historical approaches for hospitality and tourism research
}

\begin{tabular}{|r|l|}
\hline Journal: & International Journal of Contemporary Hospitality Management \\
\hline Manuscript ID & IJCHM-03-2019-0273.R1 \\
\hline Manuscript Type: & Original Article \\
\hline Keywords: & History, Methodology, qualitative research \\
\hline \multicolumn{2}{|l}{} \\
\hline
\end{tabular}

\section{SCHOLARONE Manuscripts}




\section{Purpose}

This paper shows how historical approaches can better inform understanding of hospitality and tourism research. Recent work in business and management has posited the value of historical research and narrative frameworks to explicate business phenomena - this article proposes an approach to hospitality and tourism studies could be similarly beneficial.

\section{Approach}

Three principal historical approaches are proposed: 1) systematic study of historical archives, 2) oral histories, and 3) biography and prosopography. The paper further proposes that such work should be aligned to Andrews and Burke's framework of the 5 Cs: context, change over time, causality, complexity, and contingency to help situate research appropriately and effectively.

\section{Findings}

This paper suggests that historical methods can prove particularly useful in hospitality and tourism research by testing, extending, and creating theory that is empirically informed and socially situated. The analysis put forward shows that undertaking historical work set against the framework of the $5 \mathrm{Cs}$ of historical research offers the potential for wider and deeper understandings of hospitality and tourism research by revealing temporal and historical dynamics in the field that may hitherto be unseen or insufficiently explored.

Originality/value

Much of the existing work on the benefits of historical approaches in business and management have focused on the why or the what. This article focuses on the how, articulating how historical approaches offer significant potential to aid our understanding of hospitality and tourism research.

Keywords: history, oral history, archives, biography, prosopography, methodology

Introduction

Recent work in business and management has posited the value of historical research and narrative frameworks to explicate business phenomena (Perchard, et al, 2017; Maclean, et al, 2016), but there remains opportunity in the hospitality and tourism fields for such work to further contribute to our understanding of how historical research methodologies can enhance tourism research (MacKenzie and Gannon, 2019). As hospitality and tourism studies is an integral part of business and management studies, the identification of the benefit of insights offered by historical approaches similarly applies (Decker, 2013; Rowlinson, et al, 2014; Kipping and Üsdiken, 2014). History offers excellent narrative frameworks to explicate business phenomena, but also a wealth of evidence to test and validate existing theories concerning business (Maclean, et al, 2016). Furthermore, it can be used in conjunction with existing approaches in hospitality and tourism to offer a deeper understanding of the subject. There has been a growing number of works following this approach (MacKenzie and Gannon, 2019; Maclean, et al, 2018; Paraskevas and Quek, 2019; Quek, 2012) and it is 
suggested here that there is scope for more work that goes beyond the why and addresses the how. Understanding how historical approaches can be deployed can better inform our understanding of hospitality and tourism research, which has been implicitly recognised in a number of recent works (Murdy et al, 2018; Alexander et al, 2017). This article argues that hospitality and tourism research has much to gain by incorporating historical methodologies as either discrete and/or complementary approaches alongside existing standard approaches in the discipline.

Resonating with recent calls for more historical research in management and organization studies, this paper suggests that historical methods can prove particularly useful in hospitality and tourism research by testing, extending, and creating theory that is empirically informed and socially situated (Maclean et al, 2017; Kipping and Üsdiken, 2014). The perspective put forward here follows the point raised in a number of recent contributions such as that of Perchard et al. (2017), that argue historical methods and approaches can provide excellent tools for the exploration of business phenomena. Such phenomena, as Mason and Harvey (2013) have stressed, can only be fully understood and properly examined "with reference to context, conditions and historical processes". They also highlighted how a 'reading forward' approach when it comes to exploring business ventures can provide very useful accounts of the various ways business opportunities are created and exploited, illustrating that there is much scope for the incorporation of historical research methods to complement standard approaches in tourism research.

\section{Historical theory}

Historians have been criticised in the past for not explicating their methodology sufficiently (Gaddis, 2002; Perchard et al, 2017), which may explain the lack of work examining how historical methodologies can contribute to business and management studies. To remedy this, we propose three principal historical approaches that can be of specific value to hospitality and tourism research in extending existing theories, contributing the potential for new theoretical advances, and explanation of past phenomena in the discipline. These are 1) systematic study of historical archives, 2) oral histories, and 3) biography and prosopography, as both discrete and overlapping, but complementary ways of approaching hospitality and tourism studies with historical methodologies. On their own, each of the historic approaches outlined constitute a long-standing and well-developed mode of research that have been identified and used (separately) in recent hospitality and tourism research (Huber et al, 2017; Tung and Ritchie, 2011; Trapp-Fallon, 2007 and 2003; Desforges, 2000; Ladkin, 1999). However, these approaches are still not articulated in terms of how they can be used for hospitality and tourism research going forward. We propose using the 5Cs of change over time, context, causality, complexity, and contingency (Andrews and Burke, 2007) as a unifying framework to show how the different approaches can be used either on their own, combined, or in conjunction with other more widely-used methodologies in hospitality and tourism research.

In their 5Cs framework for historical research, Andrews and Burke identify the different components as being "at the heart of the questions historians seek to answer, the arguments we make, and the debates in which we engage... to formulate and support arguments based on primary sources, as well as to understand and challenge historical interpretations related in secondary sources." (Ibid). Concomitant to this is the recognition of the importance of questioning sources and approaches. Perchard et al. (2017) recently used the 5 Cs framework to articulate the value of historical thinking to the subjects of international business, strategy, and entrepreneurship by illustrating how historical work can contribute to a better 
understanding of each. We suggest that undertaking such work set against the framework of the 5Cs of historical research (Andrews and Burke, 2007; Perchard et al, 2017) offers the potential for wider and deeper understandings of hospitality and tourism research by revealing temporal and historical dynamics in the field that may hitherto be unseen or insufficiently explored. The 5Cs represent a framework for writing history that encompasses consideration of the different ways of thinking historically. Outlined below are each with an illustrative activity explaining the potential value and approach.

\section{Historical Concept Illustrative activity \\ Change over time Analysis of non-written primary source such as a photograph illustrating how a location has changed over time. \\ Context Setting for an event, idea, or statement in which it can be understood. \\ Causality \\ Complexity \\ Contingency \\ Interpretation of partial and primary source material that provides multiple explanations for single events. \\ Triangulation of explanations to understand historical question. \\ Recognition of chance and acceptance of the interconnected nature of the world.}

Adapted from Andrews \& Burke, 2007.

Historical approaches in business and management studies in and of themselves often face challenges around data availability, composition, and interpretation (Decker, 2013). Historical research is often subject to the availability of archival materials, sufficiently complete data, and the willingness of individuals and groups to provide oral testimonies. Nevertheless, when sufficiently triangulated with other sources they form the basis of an avenue of enquiry that in of itself has a long history and sui generis value (Stokes, 2018). Historical methodologies also have the potential to complement existing methods in contemporary hospitality and tourism research. As a result of these challenges, historians will often seek to provide transparency in the sources and locations of data, triangulation with other sources, and seek out secondary data/literature to help properly situate the research in its context. This requires a near constant questioning of the data accessed as well as engagement with a wide range of source materials. The three principal historical research methodologies we consider in this article in historical research terms are archival research, oral history, and biography writing and analysis. We consider these three approaches individually and combined (including prosopographical analysis as an addendum to biography) as methodologies with great potential to help explain existing understanding, test and adapt theories, and help build new understanding in hospitality and tourism research. We consider each in order, before concluding on the value of historical methodologies to hospitality and tourism as a discipline.

\section{Archival Research}

The word archive is of ancient Greek origin and denotes the place where documents are kept, "literally the house of the magistrate, or arkheion" (Lipartito, 2013, p. 293). Archival materials are collected specifically in order to preserve the historical legacy of, usually, an organization, institution, person or place and are then gathered in certain repositories in order to be identified as an archive. Documentation may include organizational, budget and personnel records, maps, board meeting minutes, charts, survey data, censuses, registers, various statistical data produced by governments (Yin, 2009). Similarly, private and personal materials such as diaries, manuscripts, letters, memoranda and handwritten notes can also be maintained in 
archives. All of these are organization-produced documents that can be classified as archival materials and can be used as evidence in organizational research. Corporate archives are usually held by the organizations themselves but can also be kept in other institutions, very often including public or record offices and university libraries such as the Guildhall Library in London or the Baker Library at Harvard Business School (Decker, 2013, p. 161). One of the principal historical methodologies that used to study organizational fields such as hospitality and tourism is through the systematic analysis of archival materials. These can be defined as "the raw material of history" (Johnson and Williams, 2011, p. 288) or as documents and artefacts found in archival collections that are "collected for a variety of reasons, ranging from the filing of documents for marketing, legal, or other business - related requirements through to the establishment of a historical record" (Mills and Helms Mills, 2011, p. 342). Furthermore, archives are now often available online in digitised format around the world making their use much easier.

A recent example of research using archival sources for hospitality and tourism research can be found in the work of Paraskevas and Quek, (2019), who utilised material such as meeting minutes and correspondence to explore the ways Hilton Hotels managed the crisis that ensued as a result of Fidel Castro's nationalisation policies in late 1950s and 1960s Cuba (2019). This contribution highlights how useful archival sources can be when studying organizational resilience through cases of crisis management in tourism. More broadly, archival documents are valuable because they can be used to trace people and events that took place in the past and which are not accessible and researchable in any other way, often shedding light on the longerterm development of organizations, strategies, and growth. Similarly, because of their historical nature, archives allow researchers to study people, events and organizations from an evolutionary perspective offering them "a critical context in which to judge change" (Johnson and Williams, 2011, p. 292). However, archival research has been subject to a number of criticisms with one scholar arguing that it is "not properly a method of empirical organizational research because data and information are collected, rather than being directly generated in the course of the organizational research" (Strati, 2000, pp. 133-134). This is unfair in part because it does not consider the 'how' of archival research, instead focusing on the construction of data and ignoring the subjective decision-making inherent in such a process.

What does one actually do when using archives? Archival analysis requires careful consideration and questioning of source materials, triangulation with other data, and an appreciation of context both in how the materials were collected and curated, and the context in which they are being viewed. Kipping, et al. propose a methodological approach that involves the iterative use of "source criticism, triangulation, and hermeneutic interpretation" (2013, p. 306). Specifically, they suggest that a three-stage process that archival documents should be subjected to. First, a critique of the actual texts to assess their external and internal validity, that being their "authenticity and pertinence for the research question at hand". Secondly a triangulation of the information derived from these texts with the use of multiple data in order to enhance the robustness of the findings. Finally, an iterative examination of these texts from a hermeneutic perspective that situates them "within their historical contexts and in relation to other texts" (2013, p. 312-3). This latter issue of context is very important and the authors stress that researchers should always aim to assess the social, cultural and historical conditions and circumstances under which archival texts were created. With regards to the examination of the sources' validity, it should involve not only a verification of the information they present, but also an assessment of the motives of the people that contributed to the sources' creation, as well as an appreciation of the institutional context within which such creation took place. Paraskevas and Quek (2019) used a similar approach where, apart 
from primary archival material, they also considered international and domestic newspaper articles to triangulate their findings, alongside information available in history books concerning the events of the period in order to contextualise their analysis and develop the argumentation.

Moreover, the "fundamental rule of source validity is that those texts, objects, artefacts, and images that were produced during the time under study are the best primary sources" (Lipartito, 2013 , p. 289). Similarly, sources should be assessed with regards to the credibility of their creators. In this respect, researchers should examine whether those who developed the sources had the necessary degree of knowledge and competence to do so and of course whether they had any reasons to distort reality, either by changing or hiding facts (Ibid, p. 213-5). It is also important in the process of appraising archival sources to consider the role of the researcher. When using archival sources, it is critical to realise that the decisions researchers make, from the ordering of the files of the archive they will look at, to the keywords they will use in order to refine their search (in cases where searchable databases are available), can directly affect the quantity and quality of the findings and therefore also the results of their study (Pfefferman, 2016, p. 389). Such subjectivity is therefore a necessary consideration in the articulation of the methodological approaches of historians that is both reflective and reflexive in its consideration of data sources and analysis. Further, engagement with the archivist is critical - access to and success in exploring archives are dependent on the relationship and skill-set/knowledge of the archivists who can add much value to the research process; particularly in locating useful sources or having an intimate knowledge of the collections (beyond the catalogue).

It is equally important to remember that the effective use of archives presupposes knowledge of their weaknesses. Archival materials are often fragmentary (Lipartito, 2013) and "kept in a very patchy manner" (Decker, 2013, p. 157), sometimes they are created for specific audiences and purposes, therefore having necessarily limited scope (Yin, 2009), and their existence usually reflects the preferences of those who put together the archival collection in the first place (and who decide what will be included and what not). As Pfefferman notes, "archives are not neutral sites of document repository" (2016, p. 382). Similarly, in less developed countries, archives can often "suffer from autocratic suppression of information, complete lack of transparency and accountability" (Decker, 2013, p. 157), making triangulation with other sources (where possible) even more important. Nevertheless, when historians use these archives, they explicate such issues in their source discussions and offer readers direct references to location of materials ensuring transparency in the research process is embedded in their writing. From a more practical perspective, the use of archives requires knowledge of their existence (which is not always a given) and is certainly affected by the conditions in which they are kept, but also the knowledgeability of the gatekeepers (Johnson and Williams, 2011). Archivists collect, catalogue, collate, and provide access to archival materials based upon availability, purpose, and value of materials. All this suggests that archival materials should be used with caution and in combination with other sources. Moreover, as Schwarzkopf (2012, p. 4) notes, archival research is challenging not only because it can be difficult to visit the locations where archives are kept, but also because the collection of archival material is usually "time-consuming, exhausting and quite often dirty (dusty) in the literal sense of the word". Also, depending on the type of the archive, there are quite often time embargoes on the basis of privacy protection that preclude the use of some archives before a certain number of years has elapsed. In some cases, this number can vary from 25 to 50, even 100 years (Lipartito, 2013, p. 295) or more. 
When obstacles of this kind are overcome, archives have the potential to offer a wealth of information that, when used effectively, can provide valuable data for many disciplines, including hospitality and tourism research. For example, the field of ancestral and heritage tourism, where travellers aim at tracking down their own heritage and receiving an experience of what they perceive as 'homeland'. This type of tourism emerged recently and can take many different forms, a good analysis of which is presented by Halewood and Hannam (2001) in their study on the development of Viking heritage tourism from the 1970s onwards. Archival material such as censuses, registers and maps can be of crucial importance in highlighting the relationship between "tourists and the place visited", which is a core focus of heritage and ancestral tourism (Alexander, Bryce and Murdy, 2017, p. 543). Archives can provide very useful information that can be used when reconstructing and representing past events, and especially in doing so for future use such as attraction design and marketing. Also, sources such as diaries and memoirs can shed light on the thoughts and predispositions of people who lived and acted in the past. More broadly, archival records can be extremely useful in delivering the authenticity element that, as Bryce and Murdy, and Alexander (2017) stress, is an integral part of ancestral and heritage tourism.

The use of archives can provide valuable insights into the links between tourism and Corporate Social Responsibility. The work of Wells, et al. (2015) explored how successful interventions on employees' perceived satisfaction with environmental behaviours were focusing specifically on the heritage tourism workplace. Their analysis involved a longitudinal approach and produced findings which, among others, suggested that "knowledge and awareness of issues" (2015, p. 31) as well as information and feedback on employees' behaviour substantially affected satisfaction. The usefulness of archival material, which can be used as a source of knowledge and to promote awareness of the past, is almost self-evident in this respect. Archival sources are the building blocks of historical research which, as Lipartito notes, aims at presenting "a complete picture of an event or era, to reveal the features of a period in terms that reflect how actors of the time understood their world" (2013, p. 286). Wells, et al. also stressed that future studies should aim at exploring the impact of inheritance factors and intergenerational aspects of tourism and sustainability, examining, for example, the topic of fostering and promoting sustainability from one generation to the next. This argument points again to the importance of the use of archival sources and materials, which, precisely because they are historical, can allow the study of events from an evolutionary and inter-temporal perspective.

The preceding discussion demonstrates that archival research in hospitality and tourism research can be a valuable methodological approach. Archive materials can be used to uncover new insights from existing datasets and can also be used to test the robustness of existing theory in longitudinal or temporal terms by utilising new data sets that allow longer timeframes to be analysed. In this sense, and despite its very long history of usage, it offers a degree of novelty in methodological terms for hospitality and tourism research that can enhance understanding. It can be used on its own, or in conjunction with other approaches, including both contemporary and other historical methods.

\section{Oral History}

Oral history as a research approach has re-emerged somewhat in the last decade as an important qualitative methodology. A wave of recent publications reflects the growing recognition of oral history as an important research methodology in many branches of the social sciences (Maines et al., 2008; Abrams, 2010; Ritchie, 2012; Claus and Marriot, 2012; Tosh, 2013). Oral history 
relies on the recording of the spoken word in either audio or visual form. The respondents are usually interviewed in either a semi-structured or a structured format and the data, in the form of the recording, is in most cases transcribed verbatim and then analysed and examined by the researcher. This approach is beneficial for researchers who are researching timeframes in living memory and trying to reconstruct the past using first-hand accounts from people who lived the history. In this way, the recordings can be used to supplement other sources such as archival data, business records, newspapers, biographies, or as a data source in its own right. The researcher can target questions and select themes to trigger recollections of a specific period, a person or a moment in the respondent's life. Similarly, the line of questioning can be used to illicit an emotional response and reproduce feelings from an episode during the period of study.

In the construction of business histories, for example, oral histories can help the researcher reconstruct the past by using the first-hand accounts of experiences within the organization and developing lines of enquiry that help illustrate particular periods of growth, transition, crisis, conflict or alternatively, memories of job roles, practices, behaviours, people, management, customers and suppliers (Crawford and Bailey, 2019). Moreover, researchers adopting oral history have the capacity to give a voice to marginalised, unheard or overlooked groups. In addition, oral history provides opportunity to gather data from broad stratum of respondents who lived the same experience but can recall moments from their own unique perspective. This has seen oral history used in a broad range of disciplines and covering a range of important themes such as gender, sexuality, equality, race, labour and politics. It is this flexibility and adaptability of oral history research methodology that provides for the potential of oral history to make an important contribution in the field of tourism management.

Despite such potential, oral history as a research method does have some limitations and drawbacks. Memory can be an imprecise tool of analysis and can be prone to mistakes, but nevertheless offers an important avenue of research for scholars seeking to reconstruct hospitality, tourism and leisure experiences (Baastiansen et al., 2019). The inexact nature of memory can result in the recollections from respondents being clouded or influenced by the narrative and representative constructions of history that have emerged over time. The press, publications, media, films and broadcasts that have shaped our understanding of the past can influence the memories communicated by respondents and interviewees. Depending on the timeframe and periodization of the study the respondents may be elderly and aged, they can be recalling periods from a long time ago, or periods of stress, crisis or conflict that can impact on how the stories of the past are recollected and retold. Finally, memories of the past are highly subjective resulting in one person's recollections being told from a particular standpoint with importance assigned to moments, periods or people that have meaning and value to only the respondent. This results in responses being subject to the particular interests, prejudices and neutralities of that particular person. As Claus and Marriott (2012, p. 416) explain, "oral history concerns itself by definition with living memory which itself places inescapable temporal limits on its area of enquiry... Veracity and accuracy is another criticism often levelled at oral history. Memory is inherently selective, faulty, deluded and fraught with all sorts of problems as well as revealing and potentially informative". However, despite these limitations, there remains the scope for oral histories to be an important methodology in tourism research.

In terms of tourism research, oral history has the capacity to provide crucial insights into the lived experience of actors in the industry. This is not limited to holidaymakers, tourists, or consumers/customers, but also includes a wide-range of patrons such as industry representatives, travel agents, hoteliers, retailers, airlines, airports, hospitality and employees/employers. Of course, contemporary histories produced using oral histories are 
limited by the fact that human lifespan and memory may restrict studies with timeframes of more than seventy-five years. However, broader historical perspectives can be produced by piecing together and linking oral histories produced by, for example, successive generations of stakeholders; for example, a person living today may be able to recall memories from 60 years ago. This can be combined with an oral history recorded by their predecessor or parent from 50 years ago providing a broader perspective of a century of development and history.

In general terms, the intersection of tourism and history has tended to manifest in studies on the development of tourism in specific destinations, regions and places (Middleton and Lickorish, 2007; Williams, 2008; Gentry, 2015; Lazarević, 2018; Liechty, 2005; Little and Bradley, 2016; Buswell, 2011). However, what appears absent from many of these studies is the use of oral histories to supplement the wealth of documentary and/or archival research. A recent study by Bremner and Wikitera (2016, p. 263) examines the use of history in tourism but makes only rudimentary mention of how Maori histories have been "primarily communicated though a complex system of oral ancestral narratives" which leans towards the notion of oral history passed down through the generations help create a sense of collective identity. In Buswell's (2011, p. 198) study on tourism and history in Mallorca no oral histories were collated with only a single reference to an interview conducted in a local newspaper. One instance of oral history being used to supplement historical research in tourism in provided by Liechty $(2005$, p. 25) who includes an excerpt from a Nepalese executive who recalled the 'hippie' invasion in the 1960s and how this shaped the local perceptions of 'white' tourists in the region. In the main, the utility of oral history in tourism research is largely fragmented, piecemeal, and anecdotal. Nevertheless, it remains an area of rich potential, particularly in developing countries where tourism is an important driver of economic development but where also archival materials are often difficult to come by (Decker, 2013). Oral traditions and testimonies can therefore be recorded and utilised in lieu of archival holdings to develop hospitality and tourism opportunities (MacKenzie and Gannon, 2019).

There are a limited amount of studies that explore the utility of oral history as an appropriate methodology in tourism research. Towner (1988) provided some early insight into the value and function of oral history in tourism research. He suggested that oral history would be particularly useful in providing 'valuable insight into the importance of tourism for different social groups' (Towner, 1998, p. 51). Building on this he asserts that oral history would not only provide crucial knowledge on the growth of tourism in general during the twentieth century but also the growth of tourism across different social groups, for example, the less privileged (Ibid., p. 56). Likewise, Trapp-Fallon (2003) argues that oral history provides a valuable outlet for reflexive 'shared' researcher-subject interaction (2003, p. 297). This article not only provides a defence of oral history as a novel methodological approach in tourism studies but also provides an illustrative case that demonstrates how it can be used effectively. Trapp-Fallon refers to the 'life-story' (or biography) approach that involves in-depth interviews on a particular subject and provides crucial insights into the lived experience (Ibid., p. 300). This study outlines exactly how oral history can be used in providing 'meaning' to tourism and leisure; these interviews and oral recollections can contribute to the creation of narratives that then can be used in marketing, publicity and heritage studies. The narratives can also be used in conjunction with other resources such as photographs, archival and documentary data which, Trapp-Fallon believes, sheds light on the 'what cannot be seen' and, for example, reveals 'the meaning and interpretation of his or her photographs' (Ibid., p. 302).

Oral histories can be used to develop the perspectives on a time, place or location as perceived by the holidaymakers, the consumers, and the local businesses. These reminiscences can be 
valuable in allowing historians of tourism to understand the growth (or decline) of particular destinations and social, cultural and environmental impact of tourism over time. Trapp-Fallon explains the two-fold advantages of this approach in her study of the South Wales canals during the twentieth century. In the first instance the use of oral history enabled the researcher to provide insights into 'how the waterways were contextualised into everyday experience' building a history-from-below perspective that had been absent from the narratives. Furthermore, oral histories enabled her to develop a sense of how the waterways 'formed part of the physical and emotional landscape of south Wales over the 20th Century' (Ibid., p. 303). Here, Trapp-Fallon has demonstrated how oral histories can benefit historical tourism studies. Recent studies have built on this by demonstrating how oral history has been used to illustrate specific issues in leisure and tourism. For example, a study by Walton (2009, p. 788) demonstrates how oral histories and life stories collected from ordinary tourism workers has contributed to our understanding of labour rights in Las Vegas. Similarly, a study by Tung and Ritchie (2011) uses the reminiscences of 42 interviewees to uncover details of identity formation, family milestones, relationships and nostalgia in the senior travel market. These papers provide evidence of how oral histories have been used successfully in recent travel and leisure studies.

This section has demonstrated how oral histories can be used as an important methodology in tourism studies. There is much scope for oral histories to complement the traditional research methods used in tourism and leisure studies. Oral history, for example, can supplement documentary analysis of textual resources such as brochures, pamphlets, travel diaries and memoirs. Oral history can be used in conjunction with photographic evidence. Photographs can often provoke reminiscences that can help build a narrative around a particular period, timeframe, region and destination. Oral histories can help build the perspective of holidaymakers, holiday destinations and stakeholders who can recall their lived experiences. These are crucial in helping researchers to understand the growth and decline of particular places and the social, cultural, economic and environmental impact this has had on resident populations. Collecting several oral histories can provide a broader perspective from different viewpoints on developments within in the tourism industries over time. The data collated during the process of conducting oral histories has the potential to be a rich source of information that can be used by tourism industry representatives in marketing and publicity. This can be used as a source of competitive advantage, especially in generating interest in destinations. Moreover, there is scope for the use of oral history to contribute to specific areas of tourism research. Especially in relation to issues of cultural heritage, the development of popular destinations and the sense of identity that encapsulates regions and places around the world.

\section{Biography and Prosopography}

Biography is a well-established form of writing in business and management studies (Fellman, 2014), particularly in studies on successful business people. A number of recent works (Maclean et al., 2017; MacKenzie and Gannon, 2019) have emerged suggesting that intrinsically historical methods such as biography can help reveal new insights. In hospitality and tourism studies, a number of international hoteliers and hospitality magnates have been profiled in biographies and autobiographies, including Conrad Hilton (Maclean et al., 2017), Bill Marriott (Marriott and Brown, 2013), Cesar Ritz (Barr, 2018), and Kemmons Wilson of Holiday Inn (Kerr and Wilson, 1996). Biographies often provide revealing accounts of industry leaders (Huber et al, 2017) which can illustrate the value of individual historical analysis at the micro level. Taken as collective analysis in the form of prosopography, collective biographical 
studies offer the potential for reading across a range of spatial, temporal, environmental, and cultural dimensions. A particular strength of biographies as a resource in hospitality and tourism studies is demonstrated by their ability to cast light on individuals at a variety of levels: from the experiences of a successful founder and CEO, through to a single traveller. The centrality of focus on individual actors allows for a deeper examination of a subject or phenomenon that can often yield new insights that cannot be drawn as easily from quantitative approaches. Such biographies are interesting but can remain discrete stories of singular success or failure. Taken collectively as the basis for prosopographical analysis however, they can offer potential for exploring patterns across different periods and places that can unveil commonalities in explaining explanatory factors in certain outcomes.

Biographies are typically written on individual subjects, and usually with access to private documentation such as diaries, correspondence, notes, company documents, and sometimes using oral histories collected from the subject themselves. They can be based solely on interviews with the subject (and those who know/knew the subject), access to official documentation, questionnaires, press reports, and other sources of knowledge on the subject; or they can be based on no access at all to the subject (sometimes called 'unauthorised' biographies). Autobiographies (which can often be ghost written by anonymous authors) are typically based on the recollection and retelling of past events and decisions taken by the subject but are also subject to memory decay. What this requires then, in all instances, is triangulation on the part of the biographer to ensure that the subject matter is treated with as much objectivity as possible should this be the desired approach (some biographies are paid for by subjects where objectivity is not necessarily desired, resulting in hagiographies). Triangulation of materials, sources, and even perspectives is often necessary for historians seeking to understand silences, missing information, and potential misinformation (Decker, 2013 ) in the writing of biographies. The 5 Cs can then be utilised as a framework by historians in understanding and undertaking such research. For the purposes of hospitality and tourism research, deploying the $5 \mathrm{Cs}$ ensures historical thinking is present in the research process as well as in the execution of the work. Concomitant to this is the recognition of the duality of purpose in historical research to both reveal and explain development over time.

The art of the biography is one that treads a fine line between hagiography and cynicism (Elsner, 1997), so should be treated with care by scholars seeking to utilise its methods. The long history of biographies illustrates both an existing resource and a potentially rich opportunity for hospitality and tourism scholars seeking to widen their methodological approaches in pursuit of knowledge in the field. For example, seeking to understand certain firm strategies could be revealed through an in-depth analysis of the CEO's career for a topdown analysis, or through the lived experience of hospitality workers at the bottom of the economic pyramid (Walton, 2009). Depending on the issues being analysed biographies offer a well-established in-depth approach to understanding individual behaviours, achievements, and engagements with their surroundings in a way that other methodologies cannot. Used as building blocks for prosopographical analysis, the individualistic nature of the subject material can be mitigated by reading across and between cases to help build new theory in line with approaches elsewhere in the contemporary business and management discipline (Eisenhardt and Graebner, 2007).

Prosopography has a long history of usage, dating back to the sixteenth century (Barnes, 2007, pg. 72), and is the method of collective biography or reading across multiple biographies to glean insights into certain phenomena. The English historian Lawrence Stone wrote of prosopography as "the investigation of the common background characteristics of a group of 
actors in history by means of a collective study of their lives" (Stone, 1971, pg. 46). Recent work has described it as "a means of profiling any group of recorded persons linked by any common factor" (Magdalino, 2003, pg. 44). Prosopography lends itself well to studies of certain industries and organizations due to its need for clear parameters in analysing groups. This is demonstrated by the classic business history works by Erickson (1959) and Crouzet (1985), and more recent work by Fellman (2014). For a subject like hospitality and tourism management, prosopographical analysis has the dual benefit of offering qualitative and quantitative methodological approaches. These enable both micro-level deep dive work into the behaviours of individuals, and broader generalisations of group behaviours over time. Prosopography provides the option of focusing on a broad stratum of groups such as families, owners, workers, users, or other stakeholders (policymakers, investors, entrepreneurs, other government officials, etc). Given that hospitality and tourism management is focused on multiple territories and time periods, prosopographical analysis offers significant potential due to its focus on spatiality and temporality. Consequently, it allows for both the creation and testing of new and existing theories in line with a number of recent calls in business and management studies (Maclean et al, 2017; Kipping and Üsdiken, 2014).

Prosopography has typically focused on the analysis of patterns of behaviour amongst elites (Cassis, 2002; Fellman, 2014) in part because biographies tend to be written about such people. One approach could then be used in hospitality and tourism studies through the deployment of prosopography to analyse for example web-based datasets of biographies such as Who's Who, or the Oxford Dictionary of National Biography, both of which are significant historical resources for scholars. Further, with the advent of Big Data, prosopographical analysis could be deployed with fuzzy-set qualitative comparative analysis to offer a further opportunity to utilise its methodological approach to build better understanding of large-scale biographical datasets. Alternatively, the existence of a large number of travel biographies could allow for prosopographical analysis to be deployed in analysis of the experience and motivations of travellers and other actors in the field. Similarly, with the growing amounts of data being collected across every sector of the tourism industries, prosopography can help with building profiles of tourists, operators, owners, and other stakeholders.

Recent work by Booth uses prosopography as "a distinctive research method to recover the lives of groups of people” (Booth, 2016, pg. 63). By using biographies as her dataset, Booth explores literary tourism and examines what draws tourists to certain locations, illustrating a contemporary use of the method. The dataset that Booth used was the Collective Biographies of Women database covering the period 1830-1950, containing 8600 individual biographies gleaned from 1200 books that contained three or more short biographies of women (University of Virginia, 2019). From there Booth explores the homes of writers across spatial (U.K. and U.S.A.) and temporal (eighteenth and nineteenth centuries) dimensions to explain literary tourism behaviours, revealing new insights into the subject that would otherwise have remained hidden from view. In this sense, biographies can offer a window in the past that help us understand how popular destinations and heritage sites have emerged throughout history. She then uses multiple biographies in this way to develop her analysis accordingly. Such uses of prosopographical analysis in hospitality and tourism research remain relatively rare however, despite its potential to aid understanding and use of existing knowledge and datasets. Unveiling commonalities across subjects, time, and place and using parameters such as literary tourism conditions helped Booth illustrate the potential of the methodology as well as how to engage other subjects and methods in her work - without prosopography such work would not have been possible. 


\section{Discussion}

Each of the three historical methodologies outlined above offer significant potential to aid our understanding of hospitality and tourism research on three levels: on an individual basis; combined with each other; or supplementary to other existing widely used methodologies. This study has demonstrated the benefit of each of the three approaches. Each historical methodology covered here is well-established in other disciplines with significant canons of work available to show hospitality and tourism scholars the value of historical methodologies if considered and deployed appropriately.

Insert table 1 Historical Methods about here.

Concomitant to this is the importance of adherence to the $5 \mathrm{Cs}$ articulated by Andrews and Burke in helping appropriately situate historical thinking into such approaches. By considering the importance of change over time, context, causality, contingency, and complexity in the field of hospitality and tourism, researchers can utilise this framework in their projects to derive both intellectual and practical benefits.

In practical terms, the above approaches have been utilised in hospitality and tourism management in the Scotch whisky industry to develop a number of attractions and sector-led approaches to building capacity in the industry based on the value of historical approaches. Scotch whisky tourism comprises over 1.9 million visitors per year to distilleries, with spending of around $£ 61$ million. (Scotch Whisky Magazine, 2019). Scotch whisky tourism has developed over the last thirty years with an explicit focus on the heritage and history of whisky distilling in Scotland. Stretching from the capital Edinburgh to the most peripheral areas of the country, Scotch whisky tourism has developed along historical lines of whisky distilling locations utilising historical narratives of people, place, and heritage to create hospitality and tourist destinations across the country (Visit Scotland, 2019a). Distillery tours extoll the historical nature of the spirit's distillation, highlighting the changing role of individual whisky pioneers, entrepreneurs, families, and their locales (Visit Scotland, 2019b). Consistent within this is recognition of the $5 \mathrm{Cs}$, as well as the three main historical approaches outlined in this paper - many of the distilleries utilise oral testimonies of former workers, biographies of owners, and archival documentation such as distilling notes or ledger books to create immersive tourist experiences focused around whisky's heritage and history.

By building narratives around the brands, the history of the distilleries themselves, and the development of the sector, Scotch whisky has utilised each of the different constituent parts of the $5 \mathrm{Cs}$ to create practical outcomes for hospitality and tourism development purposes. The industry has deployed change over time to illustrate innovation in the industry, causality to celebrate the achievements of its production and distribution successes in growing a global industry, contingency in identifying and lauding the actions of key entrepreneurs, and complexity in reinventing itself around the variety of whiskies now available in the market and celebrating the heritage of this. The outcome of these activities has been the creation of a certain mythology around the industry's heritage which has created significant opportunities for hospitality and tourism activities as an adjacent and growing supplementary industry in Scotland. Similar outcomes could be achieved elsewhere in the world with identification of historical assets to create hospitality and tourist attractions based upon heritage, traditions, and natural assets.

Conclusion 
Hospitality and tourism research is a pluralistic subject that encompasses a wide range of research methodologies that have combined to offer a more holistic and detailed understanding of the subject. Surveys, ethnographies, diaries, content analysis, semi-structured interviews and panel data analysis, amongst other approaches, have all been deployed to better understand the subject over the years, often with an overt focus on contemporary understanding rather than the development of phenomena or understanding over time. On this basis, historical methods such as archival research, oral histories, and biography and prosopography have largely been overlooked. This presents the opportunity for hospitality and tourism scholars to incorporate these historical methods and further develop their interest and understanding of the subject. Consistent within this is a recognition that knowledge is incomplete and developing. This requires then a wider perspective on the subject that encompasses not only analysis of the present and recent, but also of the wider and longer run past. Historical methods allow for this if used carefully and consistently and can unveil patterns of change, the role of contingency, and, of course, change over time. For researchers in hospitality and tourism seeking to expand their range of research methodologies, historical approaches offer the dual benefit of both transparency in data and methodological rigour allowing for a more complete research approach.

\section{References}

Abrams, L., (2010), Oral History Theory, New York, Routledge.

Alexander, M., Bryce, D., and Murdy, S. (2017), "Delivering the Past: Providing Personalized Ancestral Tourism Experiences", Journal of Travel Research, Vol. 56(4), pp. 543-555.

Andrews, T. and Burke, F. (2007), "What Does It Mean to Think Historically?" Perspectives in History: http://www.historians.org/publications-and-directories/perspectives-onhistory/january-2007/what-does-it-mean-to-think-historically Accessed 24/06/2019.

Bastiaansen, M., Lub, X. D., Mitas, O., Jung, T. H., Ascenção, M. P., Han, D., Moilanen, T., Smit, B., Strijbosch, W. (2019), "Emotions as core building blocks of an experience", International Journal of Contemporary Hospitality Management, Vol. 31 Issue: 2, pp. 651668.

Barnes, T. (2007), "Prosopography Modern and Ancient' in Keats-Rohan, K.S. ed. Prosopography approaches and applications: A Handbook(Vol. 13). Prosopographica et Genealogica.

Barr, L., (2018), Ritz and Escoffier: The Hotelier, the Chef, and the Rise of the Leisure Class. New York, Clarkson Potter.

Booth, A. (2016), Homes and Haunts: Touring Writers' Shrines and Countries. Oxford and New York, Oxford University Press.

Bremner, H., and Wikitera, K., (2016), “Using history for tourism or using tourism for history? Examples from Aotearoa/New Zealand.' Journal of Tourism History, 8(3), pp. 260-274

Bryce, D., Murdy, S. and Alexander, M. (2017), "Diaspora, authenticity and the imagined past", Annals of Tourism Research, Vol. 66, pp. 49-60.

Buswell, R. J. (2011), Mallorca and tourism: history, economy and environment, Buffalo, Channel View Publications

Cassis, Y. (2002), “Business elites and business history', in Historical perspectives on corporate governance: reflections on ownership, participation and different modes of organizing, edited by Fellman, S., Kuustera, A., \& Vaara, E. Helsinki, Finnish Society for Science and Letters, pp. 25-36. 
Claus, P. and Marriott, J., (2012), An Introduction to Theory, Method and Practice: History. Oxon, Routledge.

Crawford, R. and Bailey, M. (2019), "Cousins Once Removed? Revisiting the Relationship between Oral History and Business History.' Enterprise \& Society, 20(1), pp. 4-18.

Crouzet, F. (1985) The First Industrialists: The Problem of Origins, Cambridge, Cambridge University Press.

Decker, S., (2013), "The silence of the archives: Business history, post-colonialism and archival ethnography', Management \& Organizational History, 8(2), pp. 155-173.

Desforges, L. (2000), "Travelling the world. Identity and travel biography." Annals of Tourism Research, 27(4), pp. 926-945.

Eisenhardt, K. M., and Graebner, M. E. (2007), "Theory building from cases: opportunities and challenges", Academy of Management Journal, 50(1), pp. 25-32.

Elsner, J. (1997), "Hagiographic geography: travel and allegory in the Life of Apollonius of Tyana", The Journal of Hellenic Studies, 117, pp. 22-37.

Erickson, C. (1959), British Industrialists: Steel and Hosiery, 1850-1950, Cambridge, Cambridge University Press.

Fellman, S. (2014), "Prosopographic studies of business leaders for understanding industrial and corporate change', Business History, 56(1), pp. 5-21.

Gaddis, J. L. (2002), The Landscape of History: How Historians Map the Past, Oxford: Oxford University Press

Gentry, K. (2015), History, heritage, and colonialism: Historical consciousness, Britishness, and cultural identity in New Zealand, 1870-1940, Manchester: Manchester University Press Halewood, C. and Hannam, K. (2001), "Viking Heritage Tourism, Authenticity and Commodification', Annals of Tourism Research, Vol. 28, No. 3, pp. 565-580

Huber, D., Milne, S. and Hyde, K.F., (2017), “Biographical research methods and their use in the study of senior tourism.' International Journal of Tourism Research, 19(1), pp.27-37.

Janesick, V. J., (2010), Oral History for the Qualitative Researcher: Choreographing the Story, New York, Guilford.

Johnson, V., and Williams, C. (2011), "Using Archives to Inform Contemporary Policy Debates: History into Policy?", Journal of the Society of Archivists, 32:2, pp. 287-303.

Kerr, R, and Wilson K. (1996), Half Luck and Half Brains: The Kemmons Wilson, Holiday Inn Story. Nashville, TN, Hambleton-Hill Publishing, Inc.

Kipping, M. and Üsdiken, B., (2014), "History in organization and management theory: More than meets the eye.' The Academy of Management Annals, 8(1), pp. 535-588.

Kipping, M., Wadhwani, R.D., and Bucheli, M. (2013), "Analyzing and Interpreting Historical Sources: A Basic Methodology". In Organizations in Time: History, Theory, Methods, M. Bucheli and R. D. Wadhwani (eds), pp. 305 - 329. London, University Press Scholarship Online - Oxford Scholarship Online.

Ladkin, A. (1999), "Life and work history analysis: The value of this research method for hospitality and tourism", Tourism Management, 20(1), pp. 37-45.

Lazarević, Z., (2016), "History of Tourism Research in Slovenia', History and Tourism Management, 4(1), pp. 7-20

Liechty, M., (2005), "Building the Road to Kathmandu: Notes on the History of Tourism in Nepal. Himalaya", The Journal of the Association for Nepal and Himalayan Studies, 25(1), pp. 19-28.

Lipartito, K. (2013), "Historical Sources and Data", in Organizations in Time: History, Theory, Methods, edited by M. Bucheli and R. D. Wadhwani, pp. 284- 304. London: University Press Scholarship Online - Oxford Scholarship Online.

Little, J, I., and Bradley, B., eds. (2016), Special Issue on “'The History of Tourism in Canada.' Histoire Sociale/Social History 49, no. 99. 
MacKenzie, N. G. and Gannon, M. J. (2019), "Exploring The Antecedents Of Sustainable Tourism Development', International Journal of Contemporary Hospitality Management. doi: 10.1108/IJCHM-05-2018-0384

Maclean, M., Harvey, C. and Clegg, S.R., (2016), “Conceptualizing historical organization studies', Academy of Management Review, 41(4), pp.609-632.

Maclean, M., Harvey, C., Suddaby, R. and O'Gorman, K. (2018), 'Political ideology and the discursive construction of the multinational hotel industry", Human Relations, 71(6), pp. 766795.

Magdalino, P. (2003), "Prosopography and Byzantine Identity" in Cameron, E (ed). Fifty Years of Prosopography: The Later Roman Empire, Byzantium, and Beyond. London, British Academy, pp. 41-45.

Maines, M. J., Pierce, J, L., and Laslett, B., (2008), Telling Stories: The Use of Personal Narratives in the Social Sciences and History, Ithaca, Cornell University Press.

Marriot, J. W. and Brown, K. A., 2013, Without Reservations: How a Family Root Beer Stand Grew Into a Global Hotel Company, Diversion Books.

Mason, C. and Harvey, C., (2013), "Entrepreneurship: Contexts, opportunities and processes', Business History, 55:1, pp. 1-8,

Middleton, V. T. C., and Lickorish, L. J. (2007), British tourism: the remarkable story of growth. Oxford, Butterworth-Heinemann.

Mills, A. J., and J. Helms Mills, (2011), "Digging Archaeology: Postpositivist Theory and Archival Research in Case Study Development." In Rethinking the Case Study in International Business and Management Research, R. Piekkari and C. Welch, pp. 342-360, London, Edward Elgar.

Murdy, S., Alexander, M. and Bryce, D., (2018), “What pulls ancestral tourists 'home'? An analysis of ancestral tourist motivations", Tourism Management, 64, pp. 13-19.

Paraskevas, A. and Quek, M. (2019), "When Castro seized the Hilton: Risk and crisis management lessons from the past", Tourism Management, 70, pp. 419-429.

Perchard, A., MacKenzie, N. G., Decker, S. and Favero, G., (2017), "Clio in the business school: Historical approaches in strategy, international business and entrepreneurship", Business History, 59(6), pp.904-927.

Rowlinson, M., Hassard, J. and Decker, S., (2014), "Research strategies for organizational history: A dialogue between historical theory and organization theory", Academy of Management Review, 39(3), pp.250-274.

Stokes, R. (2018) “Journal Description', Business History.

Pfefferman, T. (2016), "Reassembling the archives: business history knowledge production from an actor-network perspective", Management \& Organizational History, 11:4, pp. 380398.

Quek, M. (2012), “Globalising the Hotel Industry, 1946-1968: A Multinational Case Study of the Intercontinental Hotel Corporation," Business History 54: 201-226.

Ritchie, D. A. (2012), The Oxford Handbook of Oral History. New York, Oxford University Press.

Schwarzkopf, S. (2012), "What Is an Archive - and Where is it? Why Business Historians Need a Constructive Theory of the Archive," Business Archives, 105: 1-9.

Scotch Whisky Magazine (2019), "Is Edinburgh the new Scotch tourism capital"? https://scotchwhisky.com/magazine/around-the-world/whisky-travel/25624/is-edinburgh-thenew-scotch-tourism-capital/ Accessed 24/06/2019.

Stone, L. (1971), “Prosopography”, Daedalus. Vol. 100, No. 1, (Winter, 1971), pp. 46-79. Strati, A. (2000), "The Methods of Empirical Organizational Research", Theory and Method in Organization Studies: Paradigms and Choices, London, Sage.

Tosh, J. (2013), The Pursuit of History, 5th edition, New York, Routledge. 
Towner, J. (1988), “Approaches to tourism history”, Annals of Tourism Research, 15, 47-62. Trapp-Fallon, J. M. (2003), "Searching for rich narratives of tourism and leisure experience: How oral history could provide an answer', Tourism and Hospitality Research, 4(4): 297. Trapp-Fallon J. (2007), "Pursuing the past: Using oral history to bring transparency to the research process", in The Critical Turn in Tourism Studies: Innovative Research Methodologies, Ateljevic I, Pritchard A, Morgan N (eds). Elsevier Ltd, Oxford, pp. 317-330. Tung V, and Ritchie B. (2011), "Investigating the memorable experiences of the senior travel market: An examination of the reminiscence bump', Journal of Travel \& Tourism Marketing 28(3), pp. 331-343.

University of Virginisa (2019), “Collective Biographies of Women", http://cbw.iath.virginia.edu/about.php Accessed 24/06/2019.

Visit Scotland, (2019a), "About whisky and the history of Scotch malt whisky", https://www.visitscotland.com/see-do/food-drink/whisky/history/ Accessed 24/06/2019.

Visit Scotland, (2019b), “Whisky” https://www.visitscotland.com/see-do/food-drink/whisky/ Accessed 24/06/2019.

Walton, J. K., (2009), "Prospects in tourism history: Evolution, state of play and future developments", Tourism Management 30: 783-793.

Wells, V. K., Manika, D., Gregory-Smith, D., Taheri, B and McCowlen, C. (2015), "Heritage tourism, CSR and the role of employee environmental behaviour', Tourism Management. pp. 399-413.

Williams, W. (2008), Tourism, Landscape, and the Irish Character: British Travel Writers in Pre-Famine Ireland, Wisconsin, University of Wisconsin Press.

Yin, R. K. (2009), Case Study Research: Design and Methods, Thousand Oaks, CA, Sage. 


\begin{tabular}{|c|c|c|}
\hline Approach & Advantages & Disadvantages \\
\hline \multirow[t]{5}{*}{ Archival Research } & $\begin{array}{l}\text { Can trace past people and events that are not accessible and } \\
\text { researchable in any other way. }\end{array}$ & $\begin{array}{l}\text { Can be fragmentary and kept in a 'patchy' manner meaning research } \\
\text { can be time-consuming and challenging. }\end{array}$ \\
\hline & $\begin{array}{l}\text { Allows researchers to study people, events and organisations from } \\
\text { an evolutionary and inter-temporal perspective. }\end{array}$ & $\begin{array}{l}\text { Often created for specific audiences and purpose, with a limited scope, } \\
\text { sometimes lack neutrality, transparency and accountability. }\end{array}$ \\
\hline & $\begin{array}{l}\text { Sources such as diaries and memoirs can deliver authenticity by } \\
\text { shedding light on the thoughts and actions of people who lived in } \\
\text { the past. }\end{array}$ & $\begin{array}{l}\text { The use of archives requires knowledge of their existence and is } \\
\text { affected by the conditions in which they are kept and the } \\
\text { knowledgeability of the gatekeepers / archivists. }\end{array}$ \\
\hline & $\begin{array}{l}\text { Can be used to uncover new insights from existing datasets, but } \\
\text { also test the robustness of existing theory in longitudinal and / or } \\
\text { temporal terms. }\end{array}$ & $\begin{array}{l}\text { Time embargoes can apply that preclude the use of some archives } \\
\text { before a certain number of years has elapsed. }\end{array}$ \\
\hline & $\begin{array}{l}\text { A source of knowledge and promotion of awareness of history, as } \\
\text { well as revealing how actors of the past perceived reality. }\end{array}$ & \\
\hline \multirow[t]{5}{*}{ Oral History } & $\begin{array}{l}\text { Can reconstruct personal histories and recollections using first- } \\
\text { hand accounts. }\end{array}$ & $\begin{array}{l}\text { Oral histories can be restricted by living memory - only providing } \\
\text { perspectives on periods of around } 75 \text { years }\end{array}$ \\
\hline & $\begin{array}{l}\text { Complementary and supplementary to traditional research } \\
\text { methodologies in tourism and hospitality by providing temporal } \\
\text { and longitudinal perspectives. }\end{array}$ & $\begin{array}{l}\text { Memories can be imprecise and imperfect - they can be subsequently } \\
\text { influenced by the press, media and television broadcasts since the } \\
\text { original event }\end{array}$ \\
\hline & $\begin{array}{l}\text { Can give voice to marginalised, unheard or overlooked social } \\
\text { groups and stakeholders. }\end{array}$ & $\begin{array}{l}\text { Oral histories collected from elderly respondents can be recalling } \\
\text { incidents of stress, crisis, loss or conflict - this affects how the } \\
\text { histories are retold }\end{array}$ \\
\hline & $\begin{array}{l}\text { By combining oral histories, a broader perspective on change and } \\
\text { development can be garnered }\end{array}$ & $\begin{array}{l}\text { Oral histories are subjective and can be influenced by personal } \\
\text { prejudices. If considered in isolation, an oral history only provides a } \\
\text { single viewpoint. }\end{array}$ \\
\hline & $\begin{array}{l}\text { Provide perspectives from a multitude of different stakeholders } \\
\text { within the tourism industry from the board room, down through } \\
\text { senior management and frontline employees; can also include } \\
\text { perspectives from external stakeholders such as customers, } \\
\text { suppliers and holidaymakers }\end{array}$ & \\
\hline \multirow[t]{3}{*}{ Biography } & Provides in depth analysis of individual actors. & Danger of hagiography. \\
\hline & $\begin{array}{l}\text { Well-established form of historical writing in business and } \\
\text { management studies }\end{array}$ & Potential for misremembering (autobiography). \\
\hline & Strong micro-level analysis. & Individualistic focus. \\
\hline \multirow[t]{2}{*}{ Prosopography } & $\begin{array}{l}\text { Importance of clear parameters lends itself well to analysis of } \\
\text { certain groups or industries. }\end{array}$ & $\begin{array}{l}\text { Challenging to manage multiple differently framed and produced data } \\
\text { sources. }\end{array}$ \\
\hline & $\begin{array}{l}\text { Reveals patterns of behaviour and thoughts amongst similar people } \\
\text { and groups. }\end{array}$ & Requires some historical knowledge to understand approach. \\
\hline
\end{tabular}


